\title{
Evaluation of the Sanitary Conditions of Head Meat, Esophagus, Diaphragm Meat, and Boning Scrap Processing
}

\author{
Elis Caroline Celestina dos Santos, ${ }^{1}$ Adelino Cunha Neto, ${ }^{1,2}$ Vinicius Silva Castro, ${ }^{1}$ \\ Ricardo Cesar Tavares Carvalho, ${ }^{3}$ and Eduardo Eustáquio de Souza Figueiredo ${ }^{1,3}$ \\ ${ }^{1}$ Animal Science Program, Federal University of Mato Grosso (UFMT), 78060-900 Cuiabá, MT, Brazil
${ }^{2}$ Veterinary Medicine Program, Federal University of Fluminense, Niterói, RJ, Brazil
${ }^{3}$ Nutrition, Food, Metabolism Program, Federal University of Mato Grosso, Cuiabá, MT, Brazil
Correspondence should be addressed to Eduardo Eustáquio de Souza Figueiredo; figueiredoeduardo@hotmail.com
}

Received 19 July 2016; Revised 15 November 2016; Accepted 5 January 2017; Published 29 January 2017

Academic Editor: José A. Beltrán

Copyright (C) 2017 Elis Caroline Celestina dos Santos et al. This is an open access article distributed under the Creative Commons Attribution License, which permits unrestricted use, distribution, and reproduction in any medium, provided the original work is properly cited.

\begin{abstract}
Enterobacteriaceae, coliforms, and Escherichia coli counts are important hygiene indicators and may be pathogenic. Thus, the aim of the present study was to determine microbiological contamination in head meat, the esophagus, diaphragm, and boning scraps and evaluate the hygienic conditions of the processing of these products. The Petrifilm ${ }^{\circledR}(3 \mathrm{M})$ method for determining Enterobacteriaceae, total coliforms, and E. coli was applied for 104 samples. APHA, European Union, PAHO/WHO, and Brazil/MAPA recommendations were followed. Bleeding and skinning knives were contaminated with E. coli (61.5\%). Regarding the meat cuts, $30.76 \%$ samples from head meat, the esophagus and the boning flap showed the presence of $E$. coli in counts up to $2 \mathrm{log} C F U / g$, while $15.3 \%$ of the diaphragm samples showed up to $1.85 \log$ CFU/g. The analyzed comminuted meat was, therefore, shown to be contaminated with $E$. coli during processing, indicating that end-products from this raw material can offer biological risks.
\end{abstract}

\section{Introduction}

Brazil currently accounts for approximately $15 \%$ of the world beef production, being the second largest producer, surpassed only by the United States, which accounts for approximately $19 \%$ of total production. Brazil is the largest exporter of this product, supplying more than 100 countries, with a higher export volume of 7.5 million tons per year [1]. To maintain this competitiveness, investments in quality programs, such as good manufacturing practices (GMP), Standard Operating Procedures (SOP), and Hazard Analysis and Critical Control Points (HACCP), are necessary.

Meat products ready to be cooked, fried, or baked, such as hamburgers, meatballs, kibbeh, hot dogs, and sausages, use comminuted meat in their formulations (head meat, esophagus, diaphragm, and boning scraps). These cuts, due to their location on the front of the carcass, can be easily contaminated during skinning and gutting and may be microbiological hazard sources to industrially processed products.
Research conducted on hygiene indicators along the production chain is essential in quality control programs implemented by industries [2]. Mesophilic aerobic organisms, Enterobacteriaceae, coliforms, and Escherichia coli are important microbial groups that can be monitored during beef processing and provide important information on the hygienic conditions of the applied procedures [3, 4]. The results may suggest poor hygiene during the industrial processes or improper handling of the products and may be used to estimate the shelf time of the product [3].

Some standards regarding equipment and utensil hygiene conditions used in bovine meat processing are defined by the American Public Health Association (APHA), the Pan American Health Organization/World Health Organization (PAHO/MS), and European Community (EC) and, in Brazil, by ANVISA regulation RDC 12/2001 and the Ministry of Agriculture, Livestock and Supply (MAPA). For bovine meat, the PAHO/MS establishes the absence of Escherichia coli in $25 \mathrm{~g}$, while the European Community (EC) allows up to 
$3.5 \log \mathrm{CFU} / \mathrm{cm}^{2}$ for mesophilic aerobic organisms and up to $1.5 \log \mathrm{CFU} / \mathrm{cm}^{2}$ for enterobacteria.

Comminuted meat is already a research target regarding verotoxigenic Escherichia coli, through the Brazilian Normative Instruction MAPA 02/2013 [5, 6]. However, the investigation of microbiological indicators of fecal and ruminal contamination is not required; yet it could generate information on the hygienic conditions of the production processes and even forecast the possible presence of pathogens belonging to the Enterobacteriaceae family. In this context, studies providing the general microbiological profile at specific points of the production chain are essential for the development of microbiological criteria that can be used in monitoring programs implemented by the industry, thus serving as basis for the control measures taken in this sector [7]. Thus, the aim of this study was to investigate microbiological contamination of head meat, the esophagus, diaphragm, and boning scraps and evaluate the hygienic conditions of the processes applied to obtain the final products.

\section{Material and Methods}

2.1. Slaughterhouse Refrigerator and Sampling. A convenience sampling was carried out in order to evaluate the normal work routine of a slaughterhouse, considering continuous variables, like handler replacement, employee training, and good manufacturing practices among others. Therefore, 13 animals of different lots, cities, and farms were used and head meat, the esophagus, and diaphragm and boning scraps of each animal were collected throughout different weeks. The samples were subjected to microbiological analyses immediately after sampling. Samplings were carried out from May to July 2015, at a slaughterhouse refrigerator, located in the state of Mato Grosso (Brazil), under permanent supervision by the Brazilian Federal Inspection Service (SIF). A total of 52 fragments of these were collected based on the recommendations by the Brazilian Normative Instruction DIPOA/DAS Number 2 of 20 August 2013.

To check the efficiency of the quality programs implemented by the slaughterhouse, four environmental collection points were chosen and swabs were obtained from bleeding, skinning, and boning knives, as well as from cutting room countertops in the boning area, totaling 104 samples, 52 environmental samples and 52 from animal fragments.

All environmental samples were collected with $3 \mathrm{M}$ Swab Samplers ${ }^{\circledR}$ containing buffered peptone water (BPW), while tissue fragments were stored in sterile plastic bags suitable for food storage. The samples from the boning area countertops were collected with the support of a sterilized field delimiter $\left(10 \mathrm{~cm} \times 10 \mathrm{~cm}\right.$, or $\left.100 \mathrm{~cm}^{2}\right)$. All samples were stored in a cooler with ice packs, transported to the laboratory, and analyzed immediately.

2.2. Microbiological Indicators. All swab samples were homogenized on a tube vortex shaker and a $1 \mathrm{ml}$ aliquot of each sample was plated on Petrifilm ${ }^{\mathrm{TM}}$ Enterobacteriaceae $(3 \mathrm{M})$, to enumerate Enterobacteriaceae (EB), and Petrifilm Escherichia coli (3M), to enumerate total coliforms (CT) and E. coli (EC), and incubated at $35^{\circ} \mathrm{C} \pm 1^{\circ} \mathrm{C}$ for 24 hours. The formed colonies were counted considering the phenotypic characteristics of each group: EB, yellow colonies associated or not with gas, formed after $24 \mathrm{~h}$; CT, red and blue colonies associated with gas, formed after $24 \mathrm{~h}$; EC, blue colonies associated with gas, formed after $24 \mathrm{~h}$. All results were expressed as colony forming units (CFU) per gram or per $\mathrm{cm}^{2}$, in accordance with the characteristic of each sample.

A $25 \mathrm{~g}$ portion was taken from each comminuted meat sample and homogenized in Erlenmeyers with $225 \mathrm{ml}$ of BPW (0.1\%), and, from this stock solution, a $1 \mathrm{ml}$ aliquot was taken and plated on Petrifilms for EB, CT, and EC counts.

The results were compared to the standards dictated by RDC Brazil/ANVISA Number 12, 2001, the American Public Health Association (APHA), Pan American Health Organization/World Health Organization (PAHO/MS), and Ministry of Agriculture, Livestock and Supply (Brazil/MAPA) and to the regulations established by the European Community (EC) to assess product quality.

\section{Results and Discussion}

The results were classified according to the indicators evaluated in the sampled utensils and equipment (Table 1) and comminuted meat (Table 2). To interpret the results, APHA recommendations for total coliforms and enterobacteria, European Union recommendations for total coliforms, $\mathrm{PAHO} / \mathrm{WHO}$ recommendations for E. coli, and Brazil/MAPA recommendations for enterobacteria on surface countertops were adopted as references.

Different contamination levels between the tools and equipment were observed, and results exceeded the microbiological standards set by the regulatory agencies (Table 1). This indicates the absence of constant cleaning procedures for the utensils and equipment used in beef processing, which may represent sources of contamination. The same was observed for the meat cuts used to obtain the final product. Similar results were observed by Barros et al. [8] and Brandão et al. [9], which identified different utensils and equipment in the beef-processing environment as important sources of contamination by hygiene indicator microorganisms.

Regarding the bleeding and skinning knives, $61.5 \%$ of the samples showed the presence of E. coli (Table 1). Bleeding of the animal with infected knives is the primary source of postmortem contamination, since bacterial contamination of the tissues is caused via bloodstream [10]. The skinning knives also showed unsatisfactory results for E. coli (Table 1), indicating probable contamination of utensils involved in that processing step [11-13], which was evidenced herein with the identification of E. coli also in boning knives and on countertops (Table 1).

Regarding the meat cuts, $30.76 \%$ of the esophagus, head meat, and boning scraps showed the presence of E. coli in counts up to $0.5,1.0$, and $1.4 \log \mathrm{CFU} / \mathrm{g}$, respectively, and $15.3 \%$ of the diaphragm samples showed the presence of $E$. coli in counts up to $1.6 \log \mathrm{CFU} / \mathrm{g}$ (Table 2). The meat cuts also had the highest average CFU/g for Enterobacteriaceae and total coliforms. The possibility of contamination by vomiting or bowel rupture during evisceration exists for the masseter muscle, esophagus, and diaphragm. The boning scraps of 
TABLE 1: Enterobacteria, coliform, and Escherichia coli count averages in utensils and equipment used in the slaughter of cattle and in meat processing in refrigerator slaughterhouses in the state of Mato Grosso, Brazil.

\begin{tabular}{|c|c|c|c|c|c|c|c|c|}
\hline Indicator & $\begin{array}{l}\text { Bleeding } \\
\text { knives }\end{array}$ & Skinning knives & Boning knives & $\begin{array}{c}\text { Boning } \\
\text { countertops }\end{array}$ & $\mathrm{APHA}^{\mathrm{a}}$ & $\begin{array}{c}\text { European } \\
\text { Union }^{\mathrm{a}}\end{array}$ & OPAS/OMS ${ }^{a}$ & BRAZIL $^{a}$ \\
\hline $\begin{array}{l}\text { Enterobacteria } \\
\text { (EB) }\end{array}$ & $\begin{array}{c}47 \pm 71 \\
15 \%(2 / 13)^{b}\end{array}$ & $\begin{array}{c}38 \pm 66 \\
7.7 \%(1 / 13)^{b}\end{array}$ & $13 \pm 21$ & $\begin{array}{c}21 \pm 28 \\
7.7 \%(1 / 13)^{b}\end{array}$ & $<100 \mathrm{CFU}$ & & & $1 \mathrm{CFU} / \mathrm{cm}^{2}$ \\
\hline $\begin{array}{l}\text { Total coliforms } \\
\text { (CT) }\end{array}$ & $\begin{array}{c}21 \pm 9 \\
7.7 \%(1 / 13)^{b}\end{array}$ & $\begin{array}{c}18 \pm 37 \\
7.7 \%(1 / 13)^{b}\end{array}$ & $11 \pm 23$ & $13 \pm 20$ & $<100 \mathrm{CFU}$ & $<100 \mathrm{CFU}$ & - & - \\
\hline E. coli (EC) & $\begin{array}{c}32 \pm 59 \\
61.5 \%(8 / 13)^{b}\end{array}$ & $\begin{array}{c}13 \pm 20 \\
61.5 \%(8 / 13)^{b}\end{array}$ & $\begin{array}{c}7 \pm 19 \\
46.1 \%(6 / 13)^{b}\end{array}$ & $\begin{array}{c}4 \pm 9 \\
38.5 \%(5 / 13)^{b}\end{array}$ & - & & Absence & \\
\hline
\end{tabular}

\pm 土: standard deviation; ${ }^{\mathrm{a}}$ microbiological standard; ${ }^{\mathrm{b}}$ percentage of samples exceeding some microbiological standards.

TABle 2: Total coliforms, Enterobacteriaceae, and Escherichia coli count averages in comminuted beef produced in a slaughterhouse refrigerator in the state of Mato Grosso, Brazil.

\begin{tabular}{lccccc}
\hline Indicator & Head meat & Esophagus & Diaphragm & Boning scraps $^{\text {OPAS/WHO }^{\mathrm{a}}}$ \\
\hline Total coliforms & $5 \pm 13$ & $2 \pm 3$ & $16 \pm 55$ & $14 \pm 41$ & - \\
Enterobacteria & $6 \pm 18$ & $20 \pm 48$ & $16 \pm 55$ & $6 \pm 55$ & - \\
E. coli $($ EC) & $3 \pm 11$ & $1 \pm 2$ & $15 \%(2 / 13)^{\mathrm{b}}$ & $31 \%(4 / 13)^{\mathrm{b}}$ & Absence \\
\hline
\end{tabular}

\pm : standard deviation; ${ }^{a}$ microbiological standard; ${ }^{b}$ percentage of samples exceeding the microbiological standard.

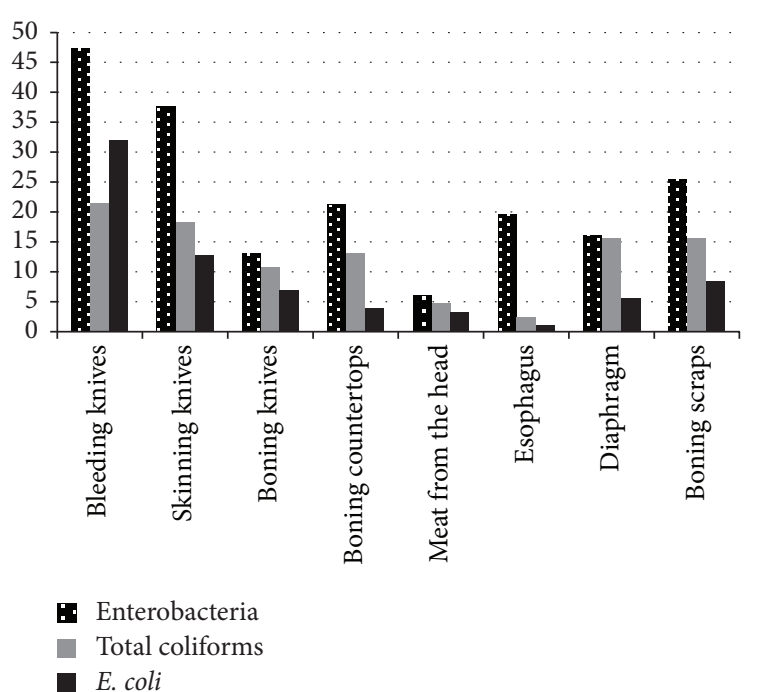

FIGURE 1: Count averages (CFU) for Enterobacteria, total coliforms, and $E$. coli in equipment, utensils, and comminuted beef produced in a slaughterhouse refrigerator in the state of Mato Grosso, Brazil.

different carcasses determine the hygienic-sanitary profile of this raw material, as they are also destined for processing. The table and boning knives were identified as the main sources of contamination of meat cuts, and bleeding and skinning knives were shown to contribute to the contamination of the meat head, esophagus, and diaphragm (Figure 1).

The RDC Number 12 of 2001 from ANVISA/BRASIL establishes microbiological standards for food. This resolution, however, does not require the analysis of total coliforms, coliforms at $45^{\circ} \mathrm{C}$, or for $E$. coli in fresh beef, either chilled or frozen, and is mandatory only for products meat products, fresh packed products, and products marketed as seasoned. Due to the lack of standards for coliforms and E. coli in the Brazilian legislation for fresh beef, the results were interpreted according to $\mathrm{PAHO} / \mathrm{WHO}$ (Table 2). The results indicate that comminuted meat is contaminated with $E$. coli during processing, regardless of the amount of hygiene indicators, and that, therefore, chilled or frozen fresh processed products produced from this raw material can also offer biological risks to consumers, since the presence of $E$. coli in comminuted meat is an important risk factor [14].

In 2004, the United States Department of Agriculture, through the FSIS Directive 6420.2, added the search for fecal contamination to self-control programs (HACCP), in head and cheek meat and the esophagus. In Brazil, few studies are being conducted to characterize and evaluate the contamination of this type of product. Recently, some Brazilian slaughterhouses were authorized to sell fresh chilled and frozen beef to the US, mainly for hamburger production and, thus, there is need for further studies devoted to the study of the microbiological profile of comminuted meats.

\section{Conclusions}

The data obtained in the present study indicate that the sanitation strategies and hygiene equipment and utensils applied in the investigated slaughterhouse were effective in reducing the microbial load arising from total coliforms and Enterobacteriaceae. They were, however, inefficient in eliminating Escherichia coli from head meat, the esophagus, diaphragm, and boning scraps, which also showed contamination by this pathogen during processing.

\section{Additional Points}

Practical Applications. This study has the potential to support the generation of microbiological criteria that can be used 
in monitoring programs implemented by the industry, thus serving as basis for the control measures regarding comminuted meat (head meat, esophagus, diaphragm, and boning scraps).

\section{Competing Interests}

None of the authors of this paper has a financial or personal relationship with other people or organizations that could inappropriately influence or bias the content of the paper.

\section{Acknowledgments}

The authors would like to thank the postgraduate course in Animal Science (UFMT/Brazil) and the funding agencies of Higher Education Personnel Improvement Coordination (CAPES/Brazil), Foundation to Support the Research of the Mato Grosso State (FAPEMAT/Brazil), and National Counsel of Technological and Scientific Development (CNPq/Brazil) that enabled the development and implementation of this research.

\section{References}

[1] ABIEC, Associação Brasileira das Indústrias Exportadoras de Carnes, Relatório anual de exportações brasileiras de carne bovina (Brazilian Association of Meat Exporters, Annual report of Brazilian beef exports), http://www.abiec.com.br/download/ relatorio-anual-2015.pdf.

[2] S. Buncic, G.-J. Nychas, M. R. F. Lee et al., "Microbial pathogen control in the beef chain: recent research advances," Meat Science, vol. 97, no. 3, pp. 288-297, 2014.

[3] Y. Ghafir, B. China, K. Dierick, L. De Zutter, and G. Daube, "Hygiene indicator microorganisms for selected pathogens on beef, pork, and poultry meats in Belgium," Journal of Food Protection, vol. 71, no. 1, pp. 35-45, 2008.

[4] K. T. Milios, E. H. Drosinos, and P. E. Zoiopoulos, "Food safety management system validation and verification in meat industry: carcass sampling methods for microbiological hygiene criteria-a review," Food Control, vol. 43, pp. 74-81, 2014.

[5] Ministry of Agriculture, Livestock, and Supply, "Procedures for the collection and analysis of verotoxigenic Escherichia coli and Salmonella spp.," in Natura Beef Used in the Formulation of Comminuted Meat Products, Ready to be Boiled, Fried or Baked, Internal Standard Dipoa/Sda No. 01, Brazil, 2015.

[6] Ministry of Agriculture, Livestock, and Supply, "Procedures for the collection and analysis of verotoxigenic Escherichia coli in In natura beef used in the formulation of comminuted meat products, ready to be boiled, fried or baked)," Internal Standard DIPOA/SDA 02, Ministry of Agriculture, Livestock and Supply, Brasília, Brazil, 2013.

[7] M. Lindblad, H. Lindmark, S. T. Lambertz, and R. Lindqvist, "Microbiological baseline study of broiler chickens at Swedish slaughterhouses," Journal of Food Protection, vol. 69, no. 12, pp. 2875-2882, 2006.

[8] M. D. A. F. Barros, L. A. Nero, A. A. Monteiro, and V. Beloti, "Identification of main contamination points by hygiene indicator microorganisms in beef processing plants," Ciência e Tecnologia de Alimentos, vol. 27, no. 4, pp. 856-862, 2007.
[9] J. L. Brandão, E. C. Guirro, P. S. Pinto, L. A. Nero, J. P. Pinto, and L. D. S. Bersot, "Monitoramento de micro-organismos indicadores de higiene em linha de abate de bovinos de um matadouro-frigorífico habilitado à exportação no oeste do Paraná," Semina: Ciências Agrárias, vol. 33, no. 2, pp. 755-762, 2012.

[10] J. M. Jay, M. J. Loessner, and D. A. Golden, Modern Food Microbiology, Springer, New York, NY, USA, 7th edition, 2005.

[11] C. M. Byrne, D. J. Bolton, J. J. Sheridan, D. A. McDowell, and I. S. Blair, "The effects of preslaughter washing on the reduction of Escherichia coli O157:H7 transfer from cattle hides to carcasses during slaughter," Letters in Applied Microbiology, vol. 30, no. 2, pp. 142-145, 2000.

[12] R. O. Elder, J. E. Keen, G. R. Siragusa, G. A. Barkocy-Gallagher, M. Koohmaraie, and W. W. Laegreid, "Correlation of enterohemorrhagic Escherichia coli O157 prevalence in feces, hides, and carcasses of beef cattle during processing," Proceedings of the National Academy of Sciences of the United States of America, vol. 97, no. 7, pp. 2999-3003, 2000.

[13] A. Serraino, L. Bardasi, R. Riu et al., "Visual evaluation of cattle cleanliness and correlation to carcass microbial contamination during slaughtering," Meat Science, vol. 90, no. 2, pp. 502-506, 2012.

[14] C. O. Gill, "Microbiological contamination of meat during slaughter and butchering of cattle, sheep and pigs," in The Microbiology of Meat and Poultry, A. Davies and R. Board, Eds., pp. 118-157, Blackie Academic and Professional, London, UK, 1998. 

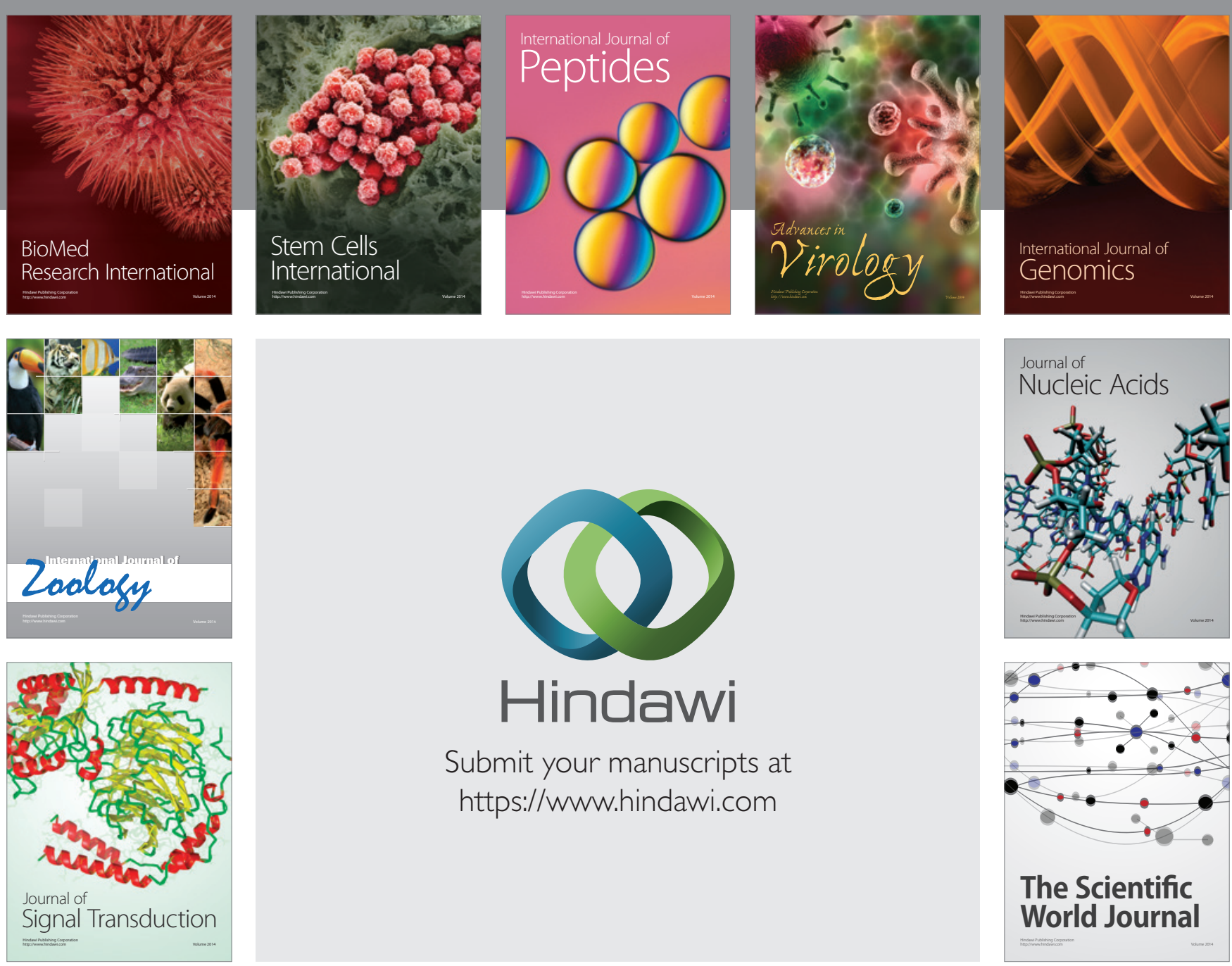

Submit your manuscripts at

https://www.hindawi.com
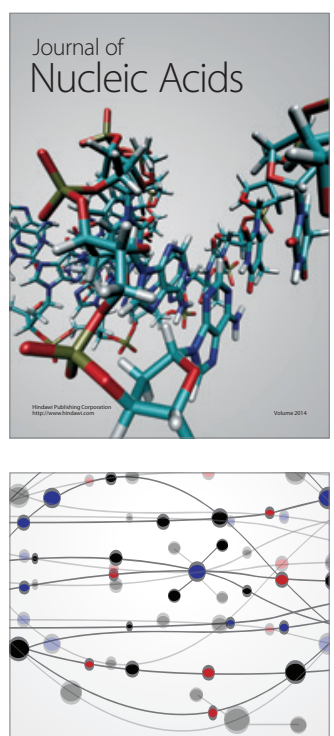

The Scientific World Journal
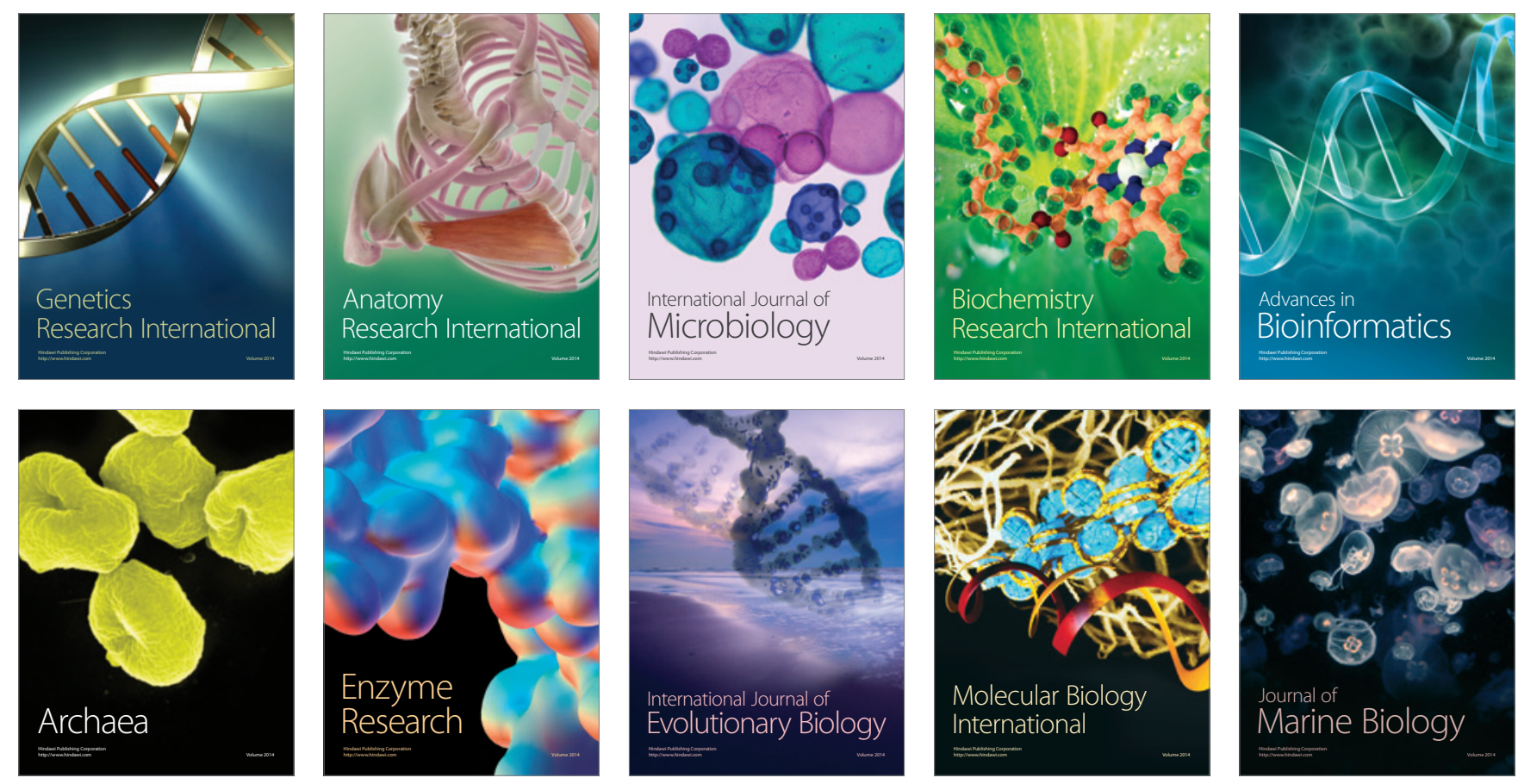